\title{
REMOVAL OF CALCIUM IN MAN BY ETHYLENEDIAMINE TETRA-ACETIC ACID. A METABOLIC STUDY *
}

\author{
BY HERTA SPENCER, VERNICE VANKINSCOTT, ISAAC LEWIN, ${ }^{1}$ AND \\ DANIEL LASZLO
}

(From the Division of Neoplastic Diseases, Montefiore Hospital, New York, N. Y.)

(Submitted for publication July 7, 1952; accepted September 5, 1952)

Ethylenediamine tetra-acetic acid (EDTAA) forms soluble complexes with divalent and trivalent metallic ions (1). This chelation was found to be preferential and depends on the $\mathrm{pH}$ of the solution. The binding power of this agent for metals is so great that once the metal is chelated it cannot be precipitated by the common precipitating agents.

Calcium was shown to form a complex with EDTAA at a $\mathrm{pH}$ above 6.5. With increasing hydrogen ion concentration, dissociation occurs and is complete at $\mathrm{pH}$ 5. The ability of EDTAA to form complexes with calcium, magnesium, lead and other metals has been studied in vitro and in vivo (2a, b; 3a, b, c, d; 4a, b, ). Rapid intravenous injection of the di-sodium salt of EDTAA (diNa-EDTA) into rabbits lowered the serum calcium precipitously to levels causing tetany; these changes could be reversed by the intravenous administration of calcium salts. On the other hand, slow intravenous injection of large quantities of this agent caused no significant decrease of the serum calcium nor any untoward effects (2a). The pharmacological properties of this agent were studied in animals (3c), and its effects upon coagulation were investigated $(2 \mathrm{~b})$.

This agent was investigated in man for the applicability of the above results obtained experimentally. An agent capable of disturbing calcium homeostasis by altering the serum calcium level would be a useful tool of investigation of mineral metabolism. It may also be of therapeutic value in states of deranged calcium metabolism. A comparison of the metabolic effects of the sodium salt with that of the calcium salt of EDTAA (di-NaCa-EDTA) appeared of interest. The latter does not interfere with calcium homeostasis and yet can exchange its calcium with endogenous ionized

* This study was supported in part by a Research Grant (C-1540 [C]) from The National Cancer Institute of The National Institutes of Health, Public Health Service.

1 Trainee, National Cancer Institute. calcium or with other metals deposited in bone $(3 a, b, c, d ; 4 a ; 5)$. Therefore, the effects of the sodium and calcium salts of this compound upon calcium metabolism were studied under controlled conditions in 10 and 5 patients, respectively (Table I). Four of these patients had no bone disease (Cases 2, 3, 8, 10), two had osteoporosis (Cases 1, 4), two had osteoblastic metastases secondary to prostatic carcinoma (Cases 7, 11), two had osteolytic metastases secondary to carcinoma of the breast (Cases 5,9) and one had multiple myeloma (Case 6).

\section{METHODS}

The patients were observed on the metabolic ward and received a low calcium diet (6). The study was divided into three phases : 1) a control period of at least six days; 2) an experimental period of six days during which one to six infusions were administered; 3) a post-infusion period of at least six days. The food, urine, and stools were analyzed for nitrogen, phosphorus, sodium and potassium as previously described $(7 \mathrm{a}, \mathrm{b})$. The calcium content of the food was analyzed in the usual way (8). After ashing of the acidified urine and stool in the muffle furnace, the urinary and fecal calcium were determined. The urine was analyzed for calcium daily, and in some instances, 24-hour urine collections were fractionated into six hour specimens. The stool analysis for calcium was performed on samples of a six-day pool. The serum calcium was determined simultaneously by direct oxalate precipitation as well as by oxalate precipitation of the acid ashed sample.

A twenty per cent solution of di-Na-EDTA was prepared and adjusted to a $\mathrm{pH}$ of 7.4 by addition of sodium hydroxide. Di-Na-Ca-EDTA was obtained as a $20 \%$ solution in ampules. ${ }^{2}$ A solution containing 4 grams of either of these salts was added to $500 \mathrm{cc}$. of 5 per cent glucose in water and was infused over a period of six hours on one to six consecutive days. Some patients received 2 grams of the sodium salt or of the calcium salt as the first dose, and two patients received 2 grams of

2 The sodium and calcium salts of EDTAA were kindly supplied by the Bersworth Chemical Company, Framingham, Mass., and by Rikers Laboratories, Inc., Los Angeles, California. The authors thank Dr. John J. Singer and Dr. George L. Maison, for their kind cooperation. 
the sodium salt daily for six days (Table I). The patients were observed during the entire period of infusion; temperature, pulse, respiration and blood pressure were determined frequently. Serum calcium was determined before and at the end of the infusion, and in some instances also at frequent intervals during the infusion.

\section{RESULTS}

Metabolic observations.-Table I shows the effects of intravenously administered di-Na-CaEDTA, of di-Na-EDTA, and of calcium glu- conate upon the 24-hour urinary calcium excretion. In four cases (Cases 2, 3, 4, 11) the comparative effects of all three substances were studied in the same patient. The calcium salt of the complexing agent was administered first, and after its effects subsided, the sodium salt was given.

Excess urinary calcium excretion was observed in every instance on the day of infusion. This excess was calculated by subtracting the 24 -hour urinary calcium excretion prior to infusion from the

TABLE I

Effect of sodium salts and calcium salts of ethylenediamine tetra-acetic acid and of calcium gluconate upon urinary calcium excretion

\begin{tabular}{|c|c|c|c|c|c|c|c|c|c|c|c|c|}
\hline \multirow{3}{*}{ Case } & \multirow{3}{*}{ Infusate* } & \multicolumn{11}{|c|}{ 24-Hour urinary calcium excretion in $\mathrm{mg}$. } \\
\hline & & \multirow{2}{*}{$\begin{array}{l}\text { Prior to } \\
\text { infusion } \dagger\end{array}$} & \multicolumn{9}{|c|}{ During infusion } & \multirow{2}{*}{$\begin{array}{l}\text { After } \\
\text { infusion }\end{array}$} \\
\hline & & & Day 1 & Day 2 & Day 3 & Day 4 & Day 5 & Day 6 & Average & Excess $\ddagger$ & $\begin{array}{l}\text { Theoretic } \\
\text { excretion }\end{array}$ & \\
\hline 1 & di-Na-EDTA & 41 & $169^{*}$ & 304 & 251 & 455 & 309 & 331 & 287 & $\begin{array}{l}m g . \\
246\end{array}$ & $\begin{array}{l}\% \\
62\end{array}$ & 55 \\
\hline $\begin{array}{r}2 \mathrm{a} \\
\mathrm{b} \\
\mathrm{c}\end{array}$ & $\begin{array}{l}\text { di-Na-Ca-EDTA } \\
\text { di-Na-EDTA } \\
\text { Calcium gluconate }\end{array}$ & $\begin{array}{l}69 \\
75 \\
70\end{array}$ & $\begin{array}{l}408 \\
288 \\
286\end{array}$ & $\begin{array}{l}389 \\
356 \\
-\end{array}$ & $\begin{array}{l}384 \\
320 \\
-\end{array}$ & - & E & - & $\begin{array}{l}394 \\
321 \\
286\end{array}$ & $\begin{array}{l}325 \\
246 \\
216\end{array}$ & $\begin{array}{l}82 \\
57 \\
48\end{array}$ & $\begin{array}{l}61 \\
61 \\
75\end{array}$ \\
\hline $\begin{array}{r}3 \mathrm{a} \\
\mathrm{b} \\
\mathrm{c}\end{array}$ & $\begin{array}{l}\text { di-Na-Ca-EDTA } \\
\text { di-Na-EDTA } \\
\text { Calcium gluconate }\end{array}$ & $\begin{array}{r}108 \\
89 \\
103\end{array}$ & $\begin{array}{l}286^{*} \\
208^{*} \\
256\end{array}$ & $\begin{array}{l}363 \\
373 \\
-\end{array}$ & $\begin{array}{l}385 \\
361 \\
-\end{array}$ & - & - & - & $\begin{array}{l}365 \\
314 \\
256\end{array}$ & $\begin{array}{l}257 \\
225 \\
153\end{array}$ & $\begin{array}{l}79 \\
63 \\
34\end{array}$ & $\begin{array}{l}118 \\
107 \\
121\end{array}$ \\
\hline $\begin{array}{r}4 a \\
b \\
c\end{array}$ & $\begin{array}{l}\text { di-Na-Ca-EDTA } \\
\text { di-Na-EDTA } \\
\text { Calcium gluconate }\end{array}$ & $\begin{array}{l}20 \\
26 \\
27\end{array}$ & $\begin{array}{l}286 \\
346 \\
159\end{array}$ & $\begin{array}{l}361 \\
344 \\
-\end{array}$ & $\begin{array}{l}354 \\
310 \\
-\end{array}$ & E & - & - & $\begin{array}{l}367 \\
333 \\
159\end{array}$ & $\begin{array}{l}347 \\
307 \\
132\end{array}$ & $\begin{array}{l}88 \\
71 \\
30\end{array}$ & $\begin{array}{l}35 \\
40 \\
43\end{array}$ \\
\hline 5 & di-Na-EDTA & 14 & 324 & 329 & 299 & 一 & - & - & 317 & 303 & 70 & 10 \\
\hline $\begin{array}{r}6 \mathrm{a} \\
\mathrm{b}\end{array}$ & $\begin{array}{l}\text { di-Na-EDTA } \\
\text { Calcium gluconate }\end{array}$ & $\begin{array}{l}54 \\
60\end{array}$ & $\begin{array}{l}432 \\
172\end{array}$ & 335 & $\frac{321}{-}$ & - & - & - & $\begin{array}{l}363 \\
172\end{array}$ & $\begin{array}{l}309 \\
112\end{array}$ & $\begin{array}{l}71 \\
25\end{array}$ & $\begin{array}{l}30 \\
65\end{array}$ \\
\hline $\begin{array}{r}7 \mathrm{a} \\
\mathrm{b}\end{array}$ & $\begin{array}{l}\text { di-Na-EDTA } \\
\text { Calcium gluconate }\end{array}$ & $\begin{array}{l}20 \\
68\end{array}$ & $\begin{array}{l}255 \\
216\end{array}$ & 279 & 236 & - & - & - & $\begin{array}{l}257 \\
216\end{array}$ & $\begin{array}{l}237 \\
148\end{array}$ & $\begin{array}{l}55 \\
23\end{array}$ & $\begin{array}{r}9 \\
85\end{array}$ \\
\hline 8 & di-Na-Ca-EDTA & 89 & 334 & 一 & 一 & - & - & - & 334 & 245 & 63 & 175 \\
\hline $\begin{array}{r}9 \mathrm{a} \\
\mathrm{b}\end{array}$ & $\begin{array}{l}\text { di-Na-EDTA } \\
\text { Calcium gluconate }\end{array}$ & $\begin{array}{l}43 \\
34\end{array}$ & $\begin{array}{l}186^{*} \\
186\end{array}$ & $\frac{194^{*}}{-}$ & $\frac{174^{*}}{-}$ & $\frac{197^{*}}{-}$ & $185^{*}$ & $172^{*}$ & $\begin{array}{l}185 \\
186\end{array}$ & $\begin{array}{l}142 \\
152\end{array}$ & $\begin{array}{l}66 \\
34\end{array}$ & $\begin{array}{l}21 \\
43\end{array}$ \\
\hline 10 & di-Na-EDTA & 85 & $215^{*}$ & $192^{*}$ & $188^{*}$ & $182^{*}$ & $130^{*}$ & $182^{*}$ & 181 & 96 & 45 & 69 \\
\hline $\begin{array}{r}11 \mathrm{a} \\
\mathrm{b} \\
\mathrm{c}\end{array}$ & $\begin{array}{l}\text { di-Na-Ca-EDTA } \\
\text { di-Na-EDTA } \\
\text { Calcium gluconate }\end{array}$ & $\begin{array}{l}18 \\
32 \\
43\end{array}$ & $\begin{array}{r}313 \\
343 \\
75\end{array}$ & - & - & E & - & - & $\begin{array}{r}313 \\
343 \\
75\end{array}$ & $\begin{array}{r}295 \\
311 \\
32\end{array}$ & $\begin{array}{r}75 \\
72 \\
7\end{array}$ & $\begin{array}{l}30 \\
84 \\
50\end{array}$ \\
\hline
\end{tabular}

* Each infusion contained $4 \mathrm{gm}$. of the sodium or calcium salt. In the cases indicated by asterisks only 2 gm. were infused. Calcium gluconate infusions contained $50 \mathrm{ml}$. of a $10 \%$ solution or $446 \mathrm{mg}$. of calcium.

Excess = Average 24-hour urinary calcium excretion during the infusion minus the pre-infusion level.

$\S$ Per cent of theoretic excretion $=\frac{\text { Excess Excretion }}{\text { Theoretic Excretion }} \times 100$. Theoretic excretion: 1 gm. di-Na-EDTA complexes with $108 \mathrm{mg}$. calcium; $1 \mathrm{gm}$. di-Na-Ca-EDTA contains $98 \mathrm{mg}$. calcium.

$t$ The average 24-hour urinary calcium excretion of a large number of patients without bone disease observed on the metabolic ward while on a low calcium diet $(150 \mathrm{mg}$. calcium/day) is $71 \pm 9 \mathrm{mg}$. Cases 2,3 , 8, 10, were normals Cases 7 and 11 had osteoblastic metastases secondary to carcinoma of the prostate with a lower than normal calcinuria characteristic for this condition (7a). Cases 4,5 and 9 received hormonal therapy for a prolonged period of time. 
CALCIUM EXCRETIONS BEFORE, DURING AND AFTER INTRAVENOUS INFUSION OF CALCIUM GLUCONATE, DI-SODIUM EOTA AND DI-SODIUM CAI.CIUM EOTA

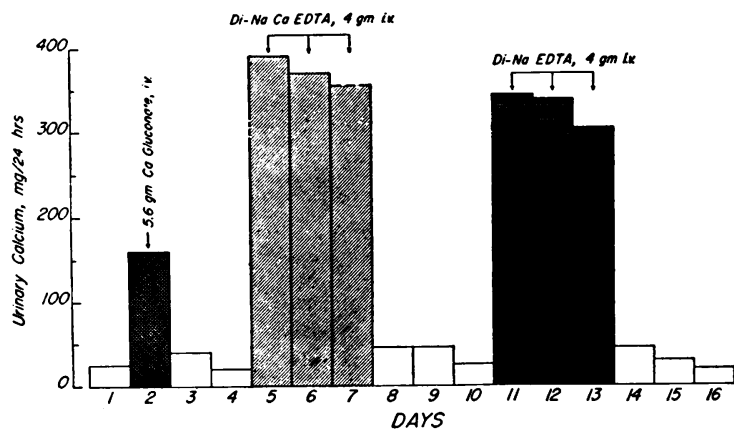

FIG. 1

average 24-hour urinary calcium excretion on the day of the infusion. The excess following the infusion of the sodium salt expressed in per cent of the expected calcium binding power of this agent, ${ }^{3}$ ranged from 45 to 72 per cent. The surplus urinary calcium excreted following the infusion of the calcium salt was somewhat higher and ranged from 63 to 88 per cent of the injected dose. The excess urinary calcium excretion following the infusion of calcium gluconate was, in every instance, significantly lower than after the administration of the salts of EDTAA (Table I and Figure 1).

The rate of urinary calcium excretion measured in six-hour intervals on the day before, during and after the infusion of di-Na-EDTA is shown in Figure 2. The first six-hour urine collection coincided with the time of the infusion. Twentyeight per cent of the excess calcium was excreted during the infusion, whereas 60 per cent was excreted in the six-hour period following the infusion. A significant excess of urinary calcium was still present in the subsequent 12 hours. When the calcium salt was administered, the maximum urinary calcium excretion was noted during the time of infusion.

The urinary calcium excretion on the day after the infusion usually approximated the pre-infusion level. Only in one out of five patients injected with the calcium salt was the calcium excretion on the day after the infusion significantly higher than on the day preceding the infusion (Case 8).

The calcium balances reflected the increased urinary calcium excretion; there was no significant

\footnotetext{
$31 \mathrm{gm}$. di-Na-EDTA complexes with $108 \mathrm{mg}$. calcium.
}

change of the fecal calcium content. The serum calcium levels determined by direct oxalate precipitation showed no significant lowering during or after the infusion of the sodium salt. However, the total calcium determined on the acid ashed serum was significantly higher during the infusion and up to 18 hours after its completion. The highest increment representing the EDTAbound calcium, non-precipitable by oxalate, was $4.3 \mathrm{mg} . \%$.

Changes of urinary phosphorus excretion and of the phosphorus balance were less constant; only in two cases (Cases 1,3) was there a marked increase in phosphaturia and a tendency toward decreased positivity of the phosphorus balance. The nitrogen and sodium balances remained unchanged. In two cases (Cases 1,4) the urinary potassium excretion was increased. In all cases studied, the levels of the serum phosphorus, sodium, potassium, and alkaline phosphatase remained unchanged.

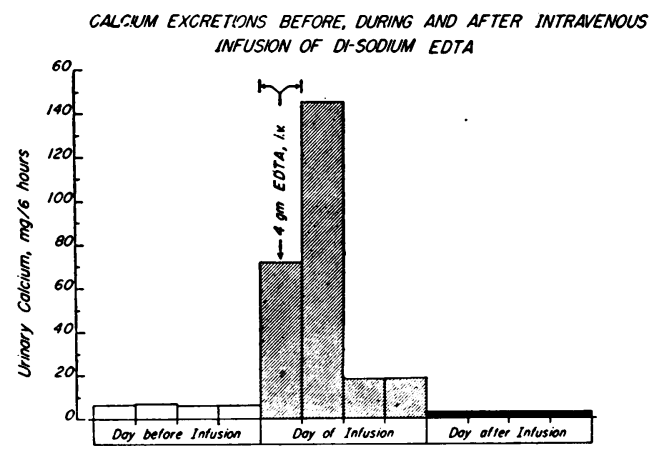

FIG. 2

Clinical observations.-No significant changes of pulse rate, temperature, or of respiratory rate were noted during the infusion. Blood counts were followed for several weeks after the administration of the salts of EDTAA and they showed no changes which might have been attributed to these agents. The urine and the blood urea nitrogen showed no abnormalities. The systolic blood pressure was significantly lowered in five out of nine cases checked during the infusion of the sodium salt (11 times out of 18 infusions) and in four out of five cases receiving the calcium salt (six times out of ten infusions), with a maximal depression of $30 \mathrm{~mm} . \mathrm{Hg}(9)$. The diastolic pressure was only occasionally lowered (maximal depression $20 \mathrm{~mm}$. $\mathrm{Hg}$ ). Although the fall of the blood pressure was 
greatest in the second and third hour of the infusion, it occurred in the first hour in one case (Case 9). It rose usually to pre-infusion levels in one to two hours after the completion of the infusion.

\section{DISCUSSION}

The present study has shown that the slow infusion of di-Na-EDTA causes no lowering of the serum calcium levels in man. This confirms earlier observations in animals (2). The maintenance of serum calcium levels, while infusing a calcium binding agent, and the concomitant excess calcinuria suggest that any decrease of the ionized serum calcium is corrected by prompt replenishment from the large calcium depots of the body, namely, from the skeletal system. This agent, therefore, causes demineralization of the skeleton, the extent and rate of which depend upon the quantity of the chelating agent and on the speed of its infusion rather than on the state of the skeletal system (normal, osteolytic or osteoblastic). At no time was the fecal calcium increased, indicating that the excess calcium excretion occurred mainly through the kidney. A maximum of 72 per cent of the theoretic value was excreted as excess in the 24 hours following the infusion. It can be assumed that the unaccounted balance is excreted in small amounts on the following days. The presence of a non-precipitable calcium in the serum 24 hours following the infusion supports this assumption. This is in agreement with the observation that the excretion of $\mathrm{C}^{14}$ labelled EDTA in animals was 99 per cent within 48 hours. $^{4}$

The high excess calcium excretion following the infusion of the salts of EDTAA and the relatively low excess excretion following the infusion of calcium gluconate is of interest. The excess excretion following the latter depends on the state of the skeletal system and on the metabolism of this substance (10), whereas the excess following the former appears to be independent, as these salts seem to be metabolically inactive.

The surplus calcium excretion following the administration of the calcium salt of EDTAA is of importance because of the exchange of injected calcium with calcium of the body or with metals deposited within bone such as radium, yttrium, and

\footnotetext{
${ }^{4}$ Foreman, Harry. Personal Communication.
}

lead $(2-4)$. These are chelated by EDTAA preferentially to calcium. The removal of these metals from the bone by exchange is of theoretical and practical importance.

The effects of the calcium salt upon calcium exchange and of sodium salt upon demineralization were studied in man by means of $\mathrm{Ca}^{45}$ and will be reported in a subsequent publication (5).

\section{SUM MARY}

1. The effect of the sodium and calcium salts of ethylenediamine tetra-acetic acid upon the calcium metabolism was studied in ten and five patients, respectively.

2. Slow intravenous infusion of the sodium salt of this agent induced excess calcinuria without lowering the serum calcium levels. This indicates prompt replenishment of the complexed serum calcium by ionized calcium mobilized from the skeletal depots.

3. The calcium salt of ethylenediamine tetraacetic acid is rapidly excreted through the kidneys.

4. The ability of this agent to remove bone salts and metals deposited in the bone has been discussed.

\section{ACKNOWLEDGMENT}

The authors wish to thank Miss Agnes Hausinger, chemist, and Miss Estelle D. Gottesman, research dietitian, for valuable assistance and suggestions.

\section{REFERENCES}

1. Schwarzenbach, G., and Ackerman, H., Komplexone XII. Die Homologen der Äthylendiamin-tetra-essigsäure und ihre Erdalkali Komplexe. Helvet. chim. acta, 1948, 31, 1029.

2a. Popovici, A., Geschickter, C. F., Reinovsky, A., and Rubin, M., Experimental control of serum levels in vivo. Proc. Soc. Exper. Biol \& Med., 1950, 74, 415.

b. Klapheke, M. A., and Rubin, M., Sodium ethylene diamine tetra-acetate as an anticoagulant for routine laboratory procedures. Bull. Georgetown Univ. M. Center, 1951, 5, 33.

3a. Rubin, M., Gignac, S., and Popovici, A., Effect of ethylene diamine tetraacetate on the distribution and excretion of lead in rabbits. Abstracts. Spring Meeting American Chemical Society, Milwaukee, Wisconsin; April 1, 1952.

b. Bessman, S. P., Ried, H., and Rubin, M., Treatment of lead encephalopathy with calcium disodium versenate. M. Ann. District of Columbia, XXI, 312, 1952. 
c. Bauer, R. O., Rullo, F. R., Spooner, C., and Woodman, E., Acute and subacute toxicity of ethylene diamine tetra acetic acid (EDTA) salts. Federation Proc., 1952, 11, 321.

d. Belknap, E. L., The diagnosis and treatment of lead poisoning-some new aspects. Presented at the 24th Annual Meeting, Lead Industries Association, Chicago, Illinois, April, 1952.

4a. Foreman, H., Decontamination studies, in Health and Biology, University of California Radiation Laboratory Report, 1950, 683, 38.

b. Foreman, H., The effect of calcium-versene complex on the excretion of radio-calcium in the rat, in Health and Biology, University of California Radiation Laboratory Report, 1950, 806, 42.

5. Bellin, J., et al., Metabolism and removal of $\mathrm{Ca}^{45}$ in man. (In preparation)

6. Bauer, W., and Aub, J. C., Studies of inorganic salt metabolism; I. The ward routine and methods. J. Am. Dietet. A., 1927, 3, 106. 7a. Laszlo, D., Schulman, C. A., Bellin, J., Gottesman, E. D., and Schilling, A., Mineral and protein metabolism in osteolytic metastases, J.A.M.A., 1952, 148, 1027.

b. Reifenstein, E. C., Jr., Albright, F., and Wells, S. L., The accumulation, interpretation and presentation of data pertaining to metabolic balances, notably those of calcium, phosphorus and nitrogen. J. Clin. Endocrinol., 1945, 5, 367.

8. Kramer, B., and Tisdall, F. F., The direct quantitative determination of sodium, potassium, calcium, and magnesium in small amounts of blood. J. Biol. Chem., 1921, 48, 223.

9. Popovici, A., Geschickter, C. F., and Rubin, M., The treatment of essential hypertension by magnesium chelate solution. Bull. Georgetown Univ. M. Center, 1951, 5, 108.

10. Schilling, A., and Laszlo, D., Rate of urinary calcium excretion following its intravenous administration as an indicator of bone metabolism. Proc. Soc. Exper. Biol. \& Med., 1951, 78, 286.

\section{SPECIAL NOTICE TO SUBSCRIBERS}

Post Offices will no longer forward the Journal when you move.

Please notify The Journal of Clinical Investigation, Business Office, 622 West 168th Street, New York 32, N. Y. at once when you have a change of address, and do not omit the zone number if there is one. 